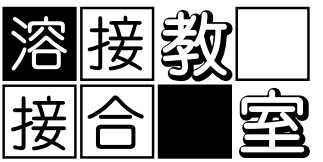

\title{
$4-1$ \\ 溶接品質マネジメントシステム*
}

和田厷 - ${ }^{* *}$

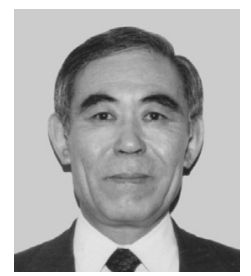

Management System of Welding Quality ${ }^{*}$

by WADA Hirokazu ${ }^{* *}$

キーワード 品質保証，品質管理，ISO3834，溶接施工要領書（WPS），溶接管理技術者

\section{1.はじめに}

世間では食品偽装に関する話題がかまびすしい，産地 偽装しかり，異種材料の混入しかり，挙句の果ては賞味 期限を改ざんするなど，およそ消費者を軽視した態度も はなはだしい. 何よりも生産者, 製造者としてのプライ ドを捨て，自社製品に対する品質の信頼性を軽視し，も つぱら短期的な経営利益を追求した姿勢は非難されて当 然であり，いずれもが大きな食中毒事件などに発展しな かったことが幸いである。

わが国の製造業，いわゆる‘ものづくり’の世界にお いても製品品質の重要性が叫ばれて久しい。戦後の一時 期, 粗悪品を輸出して世界のひんしゅくをかった時代か ら，近代的品質管理手法を導入するとともに，国民的勤 勉性による $\mathrm{QC}$ 活動，小集団活動などにより，わが国の 品質に対する信頼性を高めてきたことは，これまで自動 車，家電製品などが世界市場を席巻してきたことを考え れば十分うなづけるところである。

このように，日本独自に発展してきた品質管理活動は， これまでわが国産業界の発展に大いに貢献してきた。

一方，1970年代に, 欧米において世界的に通用する品 質保証，品質管理システム制定の動きがおこり，国際規 格 ISO9000 シリーズの誕生につながったことは周知の事 実である。

わが国でも遅ればせながら1993年, 「日本適合性認定協 会」（JAB）を設立し，製造業を中心に国際規格取得を推 奨してきた。（社）日本溶接協会も，JAB 設立に参加した 団体の一つである.

*原稿受付 平成 20 年 1 月 24 日

**正 員 近畿大学 Member, Kinki University
本稿では，溶接学会編「溶接・接合技術特論」にしたが って, 溶接構造物製造における品質管理, 品質保証の基 礎的な考え方や, 品質マネジメントシステムの内容につ いて概説する.

\section{2. 品質保証と品質管理}

\subsection{ISO (欧米型) とJIS（日本型）との比較}

簡単に言えば，欧米は，購入者（消費者）の立場に立 っているのに対し，これまでのわが国のそれはどちらか といえば造る立場, 売る立場にたった考え方といわれて いる.

参考：ISO8402-94「品質管理と品質保証の規格一用語」 によると「品質管理とは，品質方針，目標及び責任を定 め,それらを品質システムの中で品質計画, 品質管理手法, 品質保証及び改善などによって実施する経営機能の全て の活動」と定義している。

これに対し，旧来の JIS では，品質保証を「消費者の要 求する品質が十分満たされていることを保証するために 生産者が行う体系的活動」と定義されている.

また万一久陷製品を訴えられた場合には，その品質が 管理された状況下で製造, 供給されていることを証拠を 持って示す必要がある.すなわちこれまでわが国の供給 者と消費者との間で阿吽の呼吸で形成されていた信頼関 係や，「わが社を信頼してください」，「きちんとアフター サービスしますから」といった古来の日本の商習慣に根 ざした関係は通用しなくなった。

とくに溶接構造物のように，一般的にオーダーメイド であり, 品質規格や仕様の決定は顧客が行うか, その承 認が必要となるケースでは, ISO では, マニュアルを確 実に作り, 個々の任務と責任, 権限をはっきり定め, そ のマニュアルどうりに実行することが要求される.

この場合すべてにおいて文書や記録，トレーサビリテ 
イが重要となる.

\subsection{ISO9000-2000 の概要}

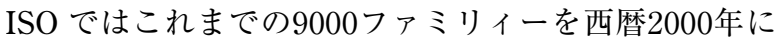
改定した。これに呼応してJISでも2000年改訂版を JISQ9000 ファミリイーとして制定，発行した.

その特徴は主として次のようなものである.

1）旧版はどちらかというと大企業，製造業向きであっ たが，中小企業やサービス業など広範な企業になじ むよう改定された.

2) QA (Quality Assurance) の用語は使用されなくな り，QM（Quality Management）に含まれるように なった。

3）新たに品質保証に加え, 顧客満足, システムの有効 性の継続的改善が追加されている.

4）この品質マネジメントシステムのモデルでは，トッ プマネジメントの役割と責任が重視され，次の原則 を採用することを勧告している.

・顧客重視：顧客ニーズを理解し, その要求事項を
満たし，顧客の期待にこたえる努力をする.

・リーダーシップ：リーダーは企業の目的，方向を 一致させ，その目標達成に参加できる環境を創り 出す.

・社員全ての参画：社員全ての階層が目的達成のた めに，その能力を活用する.

・プロセスアプローチ : Fig. 1 に示す PDCA サイク ルによるプロセスアプローチとして運用，管理さ れるとき，最も効率よく，望ましい結果が達成さ れる。

- 継続的改善：企業としてこれらの活動の継続的改 善を図るべきである.

・意思決定へのアプローチ：データ及び情報分析に 基づく意思決定がなされるべきである.

・供給者との互恵関係：下請け契約者は独立してお り，企業との間には共存共栄関係であるべきであ る.

ISO9001-2000 の要求事項の内容をTable 1 に示す.

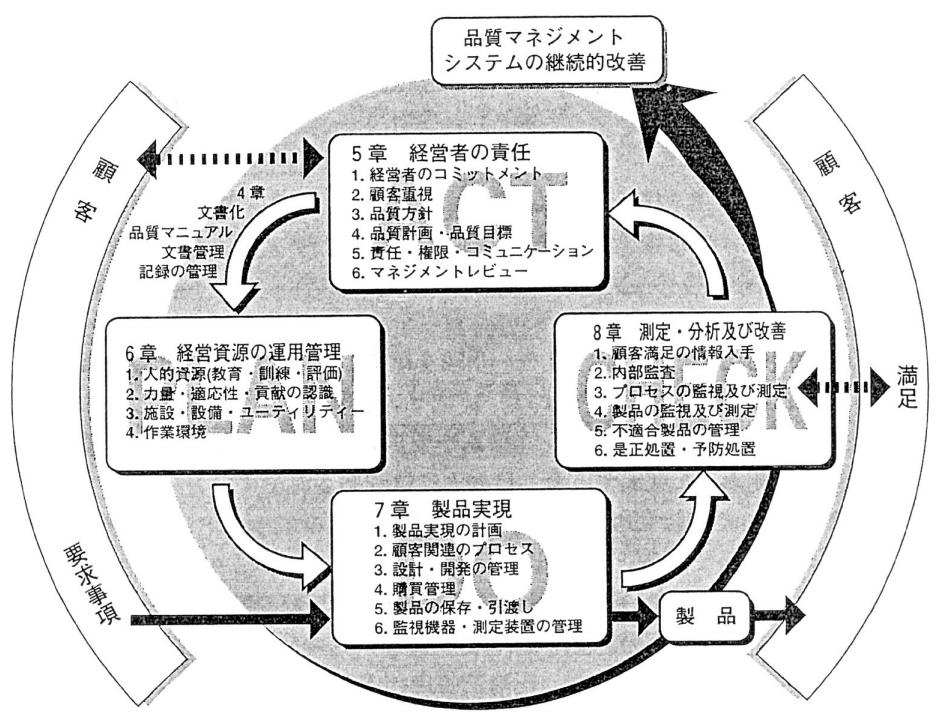

Fig. 1 PDCA サイクルによるプロセスアプローチ

Table 1 IS09000-2000 の要求事項

\begin{tabular}{|c|c|}
\hline $\begin{array}{l}. \quad \text { 品質マネジメントシステム } \\
4.1 \text { 一般要求事項 } \\
4.2 \text { 文書化に関する要求事項 }\end{array}$ & $\begin{array}{ll}7 . & \text { 製品実現 } \\
7.1 & \text { 製品実現の計画 } \\
7.2 & \text { 顧客関連のプロセス } \\
7.3 & \text { 設計・開発 } \\
7.4 & \text { 購買 } \\
7.5 & \text { 製造及びサービス提供 } \\
7.6 & \text { 監視機器及び測定機器の管理 } \\
\end{array}$ \\
\hline $\begin{aligned} & 5 . \text { 経営者の責任 } \\
& 5.1 \text { 経営者のコミットメント } \\
& 5.2 \text { 顧客重視 } \\
& 5.3 \text { 品質方針 } \\
& 5.4 \text { 計画 } \\
& 5.5 \text { 責任, 権限及びコミュニケーション } \\
& 5.6 \text { マネジメントレビュー } \\
&\end{aligned}$ & 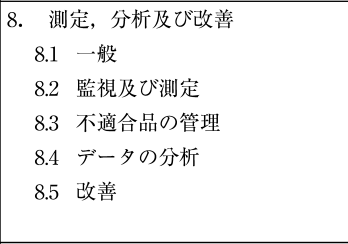 \\
\hline $\begin{array}{l}6 . \\
6.1 \text { 資源の資源の用管理 } \\
6.2 \text { 人的资源 } \\
6.3 \text { インフラストラクチャー } \\
6.4 \text { 作業環境 }\end{array}$ & \\
\hline
\end{tabular}




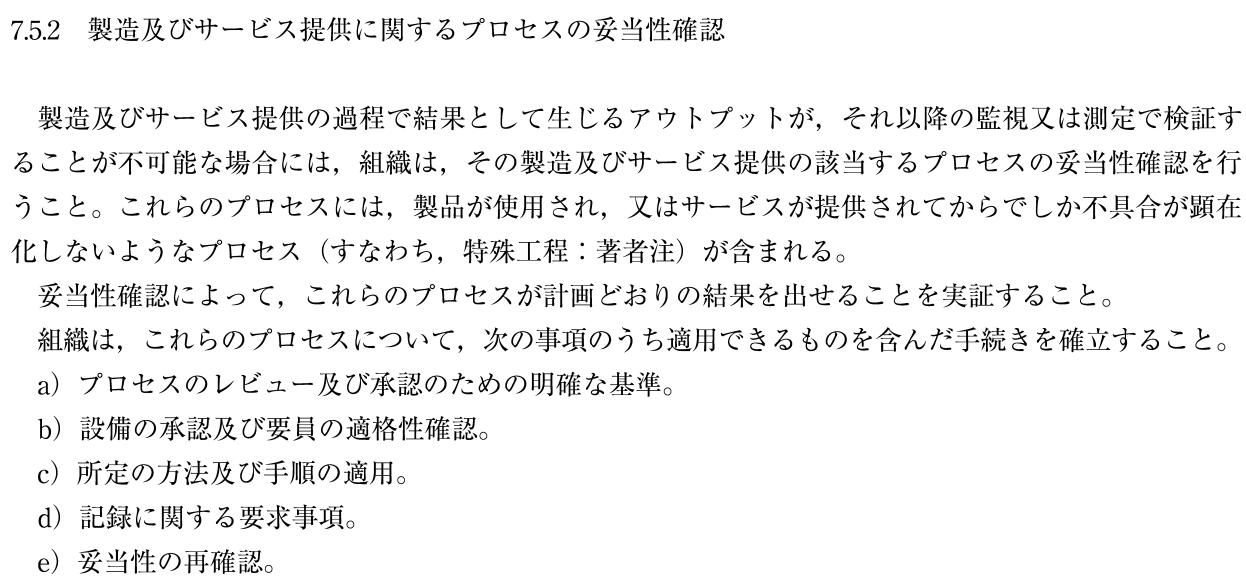

\section{IS03834 (JIS3400) による溶接 管理}

ISO9000に従って溶接管理を実施する場合には， ISO3834（JIS3400）に従って管理を行うのが妥当である.

ISO9000の初版では，溶接は「特殊工程」，すなわちそ の結果が, 後工程で実施される検査や試験では, 要求さ れた品質基準が十分満たされているかどうかを検証する ことが困難な工程と定義されていた．1994年版以降はこ の引用は削除されたが，その重要性はいっそう明確化さ れ，2000年版では，Table 2 の要求事項として記載されて いる.

ISO9000 およびISO3834に準拠して，溶接ファブリケ ー夕の品質マネジメントシステムを構築する場合の要求 事項を整理すると次のようになる.

1）プロセスすなわち「溶接施工要領」（WPS）承認のた めの基準の適用（Table 2 の a) 項）

2）使い慣れた施工要領がある場合は，その適用（c） 項)

3）溶接に従事する要員の適格性の確認（b）項）

4）溶接設備の適格性の確認（b）項）

5）溶接施工要領の重要事項についての記録（d）項）

6）重要構造物に対する施工要領の再確認（e）項） ISO3834 をべースとした規格は，2003年 JIS 化された。 これらの規格では, 溶接施工要領所の作り方, その承認 方法，承認記録の方法などが記載されている.

また要員に対しては，技術者には ISO14731（JISZ3410 として JIS 化）に基づく溶接管理技術者資格認証制度が がわが国でも発足していることは承知の事実であり，一 方技能者に対しても，ISO9606に基づく資格認証制度が 近い将来日本においてもスタートすることがほぼ決定さ れつつある。

ISO9000 および ISO3834 に準拠すると, 溶接構造物の 製造では，まず自社内に品質マネジメントシステムを確立 する必要があり，溶接品質を保証するには，次に挙げる項 目にしたがってそれぞれを確実に実施する必要がある。
（1）文書管理

製造者はここで述べる各項目の手順を明確にし，文書 化するとともに常に最新版を利用できるよう管理する必 要がある。

（2）経営資源の確保

製造者は溶接に必要ないわゆる4 M (Man, Machine, Material, Method）を明確にし，確保する必要がある。

a）要員：溶接製造の計画，施工，監視，検査及び調査 のため，十分な要員を確保し，その教育訓練 を実施する。

b）設備：設備には製造及び試験，検査，測定機器に分 類され，次に示すようなものがある.

(溶接電源, 開先加工, 切断設備, 熱処理設 備，拘束ジグなど，クレーン およびハンド リング設備, 要員の保護装置, 安全設備, 溶 接材料の保管, 乾燥設備, 破壊及び非破壊試 験装置など）

製造者はこれら設備の保守点検を計画，実施 するとともに，これらの記録を文書化してお く必要がある.とくに検査, 測定機器は校正 の記録を残す。

c）溶接材料：溶接に必要な材料の確保及びその吸湿, 酸化，損傷を避ける保管方法の確保

d）溶接手順，施工法：文書管理で示した手順書を準備 する．新規の溶接施工法は事前に確認試験を 実施する.

仕様書, 設計図面などで示される契約上の要求事項を 契約受諾前に確認する必要がある.

（3）契約内容の確認

製造者は契約上の要求事項を契約受諾前に確認し，文 書化する必要がある.

(4) デザインレビュー

製造部門においても, 設計内容を確認し, 要求事項を 満たす能力を評価し, 問題があれば解決策を提案すべく, デザインレビューを実施する.

(5) 購買管理

購入する溶接材料や製品が要求事項を満足することを 
確実にするため，下請負業者の能力を評価，選定すると ともに, 購買文書を作成し, 要求事項の妥当性を確認後 発注する。

（6）溶接施工

製造者は，溶接物を製造する手順や個々の工程を含む 施工要領書, 検査, 試験に関する要領, 環境条件などを 明確にした計画を立て, 承認された施工要領書に基づい て製造を行う。

（7）検査 · 試験

契約した要求事項に適合していることを保証するため 検査・試験を行う。検査・試験には,

1）要員の適格性証明, WPS の適合性, 溶接材料, 開 先加工, 取り付け, 作業条件の適合性などの溶接前 検査

2）溶接材料や各種溶接条件の確認, 予熱・パス間温度, 変形制御などの溶接中の検査，試験

3）外観試験, 非破壊試験を含む溶接後の検査, 試験 などがある。

（8）不適合及び是正処置

製造の結果, 要求事項を満たさない不適合品を修理す る場合は, 適切な補修要領書に従って実施し, 再検査を 行う.

（9）識別およびトレーサビリイティ

製品に使用されている材料，製造履歴などを記録され た識別によってたどる能力のことで，不適合発生原因の
追究などに有効となる.

（10）品質記録

契約要求事項への適合の証拠として定められた方法に

より保管，管理する.

溶接製造に関する品質記録としては

・契約確認,デザインレビューの記録

- 材料証明書

- 溶接施工要領（WPS）承認記録

・溶接関連要員の資格認証記録

・非破壊試験要領並びに試験結果記録 などが含まれる。

\section{4. 溶接施工要領書（WPS）の作成，承認}

特殊工程としての溶接では, その施工要領書（WPS: Welding Procedure Specification）を詳細に定め, それに 基づいて製造を実施することが品質管理上きわめて重要 となる．わが国の JISにおいても，基本的にはISOの流 れに従ってアーク溶接に関する溶接施工要領書並びに施 工法試験に関する規格が制定されており，またASME， AWSなども同様の規定を定めている.

\section{1 溶接施工要領書承認の手順}

先ずこれまでの経験, 知識により仮の溶接施工要領書 （pWPS）を作成し，これに基づいて定められた試験を実 施する。これが非破壊並びに破壊試験に合格すればそれ

Table 3 JISZ3421-1 付属書 A (参考) 溶接施工要領書

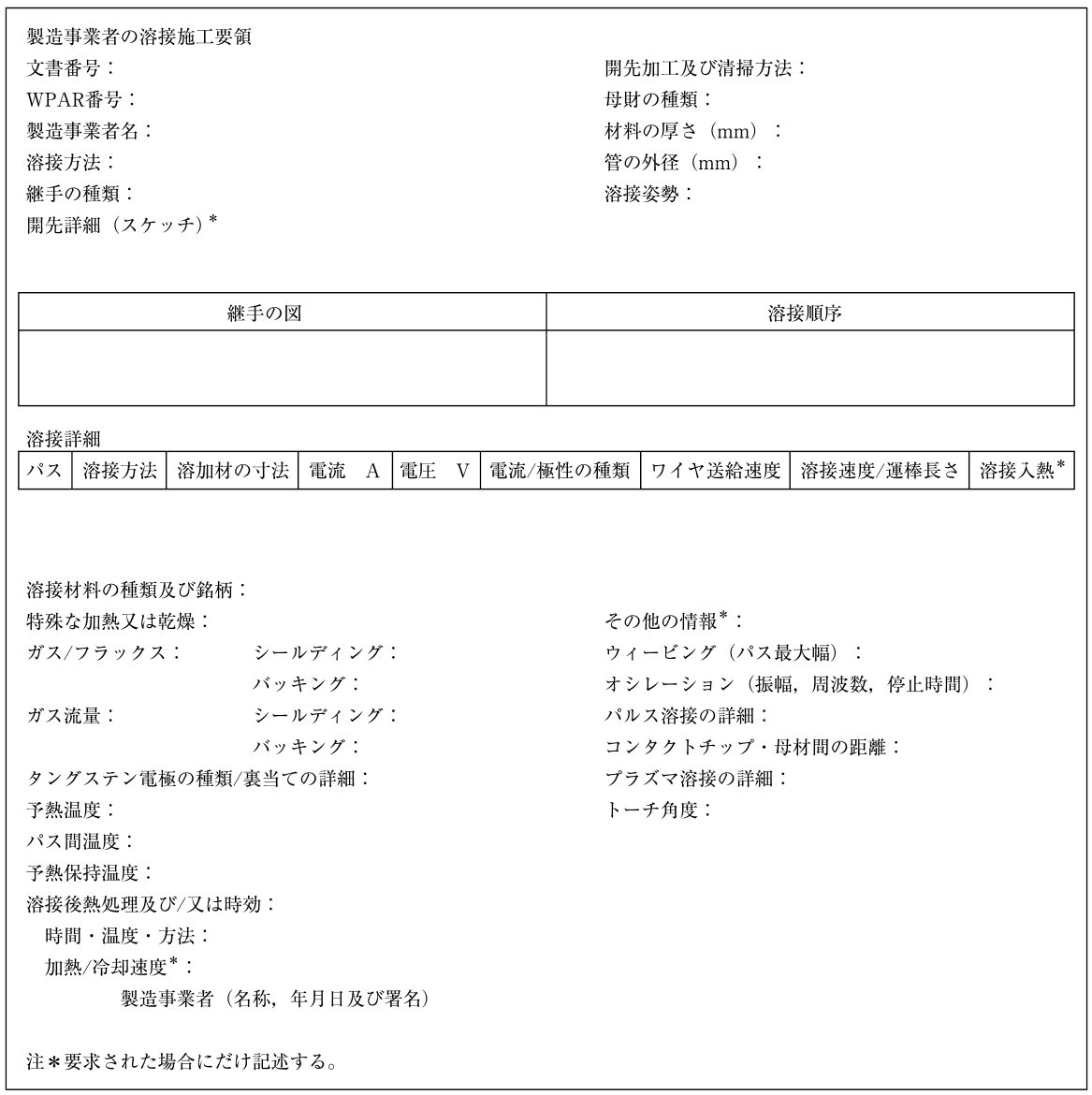


Table 4 試験材の検査および試験 (JISZ3422-1「溶接施工法試験」より抜粋)

（JIS Z 3422-1「溶接施工法試験」より报粋）

\begin{tabular}{|c|c|c|}
\hline 試験材 & 試験の種類 & 試験の範团 \\
\hline $\begin{array}{l}\text { 突合せ継手 } \\
\text { (完全溶込み) }\end{array}$ & $\begin{array}{l}\text { 目視試験 } \\
\text { 放射線透過試験または超音波探㿟試験 } \\
\text { 表面割れ検出 } \\
\text { 横方向引張試験 } \\
\text { 横方向曲げ試験 } \\
\text { 衝撃試験 } \\
\text { 硬さ試験 } \\
\text { マクロ /ミクロ試験 }\end{array}$ & $\begin{array}{c}100 \% \\
100 \% \\
100 \% \\
\text { 試験片2個 } \\
\text { 試験片 } 4 \text { 個 } \\
\text { 試験片 } 2 \text { 個 } \\
\text { 要求による } \\
\text { 試験片1個 }\end{array}$ \\
\hline $\begin{array}{l}\text { 完全溶込みT継手(5) } \\
\text { 分岐管継手 }\end{array}$ & $\begin{array}{l}\text { 目視試験 } \\
\text { 表面割れ検出 } \\
\text { 超音波探傷試験または放射線透過試験 } \\
\text { 硬さ試験 } \\
\text { マクロノミクロ試験 }\end{array}$ & $\begin{array}{c}100 \% \\
100 \% \\
100 \% \\
\text { 要求による } \\
\text { 試験片2個 }\end{array}$ \\
\hline $\begin{array}{l}\text { 板のT継手 } \\
\text { ( 部分溶込みまたは } \\
\text { すみ肉溶接) } \\
\text { 管のすみ肉溶接 }\end{array}$ & $\begin{array}{l}\text { 目視試験 } \\
\text { 表面割れ検出 } \\
\text { マクロ ミミクロ試験 } \\
\text { 硬さ試験 }\end{array}$ & $\begin{array}{c}100 \% \\
100 \% \\
\text { 試験片 } 4 \text { 個 } \\
\text { 要求による }\end{array}$ \\
\hline
\end{tabular}

は承認されたこととなり，正式な溶接施工要領書（WPS） となる。

溶接施工要領書の書式はとくに定められていないが, 使用する溶接材料, 溶接方法, 熱処理条件など, 施工上 必要事項は全て記載する. Table 3 にその一例を参考とし て示す。

\section{2 溶接施工法試験の要領}

継手形状，姿勢などにより定められた形状の試験材を 用いる。試験は非破壊及び破壊試験を含み，Table 4 の要 求事項に従う必要がある。このほか適用規格により追加 試験を要求されるケースもある.

これらの試験結果は全て溶接施工承認記録（WPAR: Welding Procedure Approval Record）として文書化し, 管理しておく必要がある.

\section{5. 国際溶接管理技術者認証制度}

わが国においては 日本溶接協会が戦後間もない1949 年，溶接技術（技能）検定制度を発足させ，また技術者 に関しては1970年に資格認定制度（WES8103）をスター 卜させて溶接業務につく要員の技能, 技術力向上を図っ て今日に至っている.

一方1990年ごろから，欧米とくにヨーロッパを中心に 国際溶接技術者資格制度構築の動きが活発となり，ISO でも先に述べた ISO3834のセット規格として「溶接管理 技術者の責任と任務」を規定した ISO14731 が制定される にいたった。

これを受け，国際溶接学会（IIW）により，ヨーロッパ 溶接連盟（EWF）の制度をよりグローバルな制度に発展 させることが検討され，1998年からその運用が開始され た。

II W の資格は一度合格すれば生涯資格となる
(Diploma)。わが国の制度はいわば検定（Certification） であり，そのつどの実務能力の継続を認証しており，そ こには考え方の違いが涊められる。しかし IIW 資格は現 存する唯一の国際制度であり, 昨今の状況ではこれを避 けて通ることはできなくなってきている.

IIW 資格には次の 4 資格があり, これらの取得には学 歴，教育時間重視の考えがある.

IWE (International Welding Engineer)

IWT (International Welding Technologist)

IWS (International Welding Specialist)

IWP (International Welding Practitioner)

わが国の WES 資格保有者に対し，短期間の講習を経て これら国際資格を付与する特例処置はすでに終了し，現 在これらの資格を取得するには，たとえばIWEに関して は，実技を含む 446 時間もの教育実績が必要となる．現 在 溶接学会も協力して, さまざまな研修, 講習会参加 者に対し，ポイントを付与することにより上記教育時間 の補填を図るべく対応がなされている.

経済のグローバル化が進展する中，溶接分野における 国際資格制度はますます重要になってくることが予想さ れる.

JISZ3410 においても，ISO14731 に準拠して溶接管理技 術者の任務と責任を規定して㧍り，それによると契約内 容の確認から, デザインレビュー, 鋼材や溶接材料の管 理, 生産計画, 溶接装置, 溶接作業自体, 試験検査, 溶 接結果の評価，それらの記録，文書化に至るまであらゆ る事項にわたって果たすべき任務が定められている.

\section{6。溶接施工計画と管理}

溶接品質のマネジメントは, 管理上最重要課題であり, 溶接管理技術者は先に述べた溶接品質を決定するあらゆ る事項に関して任務と責任が定められている。

特に溶接管理は，規則や基準，マニュアルによる管理 だけでは十分といえず，補修工事のようにルーチンから 外れた溶接施工に対して，溶接管理技術者はそのつど高 度な技術的判断と施工指示をしなければならない。欧米 の溶接関連法規でも，ところどころに技術者の裁量によ るという規定がある.

このように溶接管理技術者には，溶接工程に関する広 範な技術的任務と責任のほか, 随時の裁量に必要な包括 的な基礎知識と豊富な経験が要求される.

一方で, 鋼構造物の溶接品質を保証するための直接的 管理項目を特性要員図としてFig. 2 に示す.

また溶接施工計画には，これら全ての項目に対し QCDS（Quality, Cost, Delivery, Safety）を具体化しておく 必要がある. 計画に当たっては次の事項に配慮すること が必要となる。

1）先ずは製品の要求品質を十分把握する.

2）次に採用する各種溶接法の特徵を十分理解するとと もに，生産性向上と品質確保の両面から計画する.

3）溶接作業は設備の整った工場内でできるだけ実施する. 


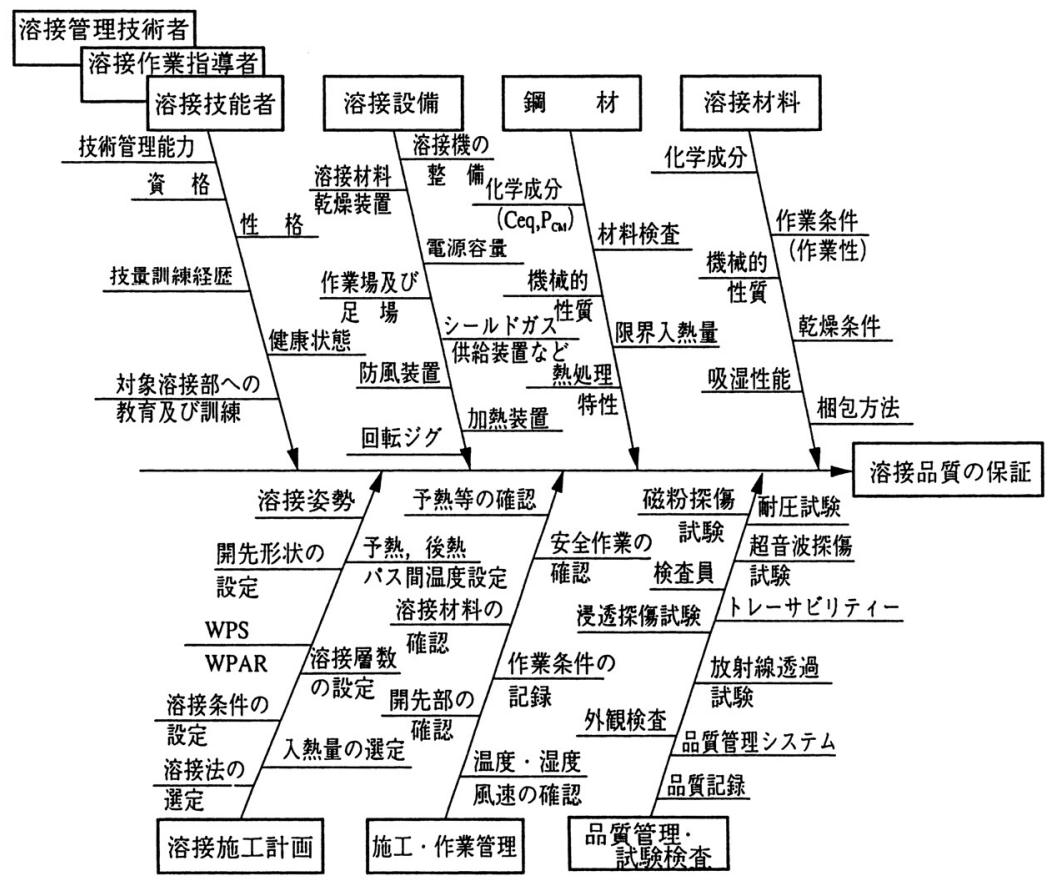

Fig. 2 溶接品質保証のための特性要因図の一例

4）溶接欠陥や過度の変形などが生じないようこれらの 防止対策を図る。

5）作業環境や安全性に対しても十分な配慮をする.

6）使用する設備能力やその保全にも十分配慮する。

7）溶接品質を記録に残す文書化に留意し，万一の事故 に対してその原因を追究できるようにしておく（ト レーサビリティ).

\section{7.あとがき}

本稿は溶接構造物における品質保証として, 溶接学会 編「新版溶接・接合技術特論」の第 4 章を抜粋して解説 したものである。
溶接技術はあらゆる産業分野の構造物の製造にとって 不可欠な技術であり，その巨大化，高機能化とともに， ひとたび事故を起こせば社会的に大きな問題となること は過去の事例を待つまでもない.

社会がグローバル化するなか, 溶接に従事するものと して，このような社会的使命を十分認識しつつ，その品 質管理, 品質保証に最大の留意して ‘ものづくり’に取 り組んでゆく必要があると考えている.

\section{参考文献}

1）溶接学会編「新版溶接・接合技術特論」産報出版。

2）平林良人「ISO9000 品質マニュアルの作り方」日科技術連 出版社. 